\title{
Recent Advances in Genome Editing Tools in Medical Mycology Research
}

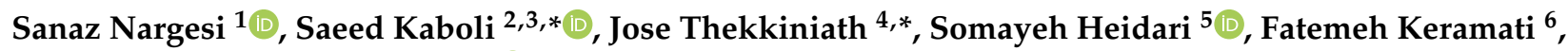 \\ Seyedmojtaba Seyedmousavi ${ }^{5,7}$ and Mohammad Taghi Hedayati ${ }^{1,5, *}$ \\ 1 Department of Medical Mycology, School of Medicine, Mazandaran University of Medical Sciences, \\ Sari 481751665, Iran; nargesi.sanaz@gmail.com \\ 2 Department of Medical Biotechnology, School of Medicine, Zanjan University of Medical Sciences, \\ Zanjan 4513956111, Iran \\ 3 Cancer Gene Therapy Research Center, Zanjan University of Medical Sciences, Zanjan 4513956111, Iran \\ 4 Fuller Laboratories, 1312 East Valencia Drive, Fullerton, CA 92831, USA \\ 5 Invasive Fungi Research Center, Communicable Diseases Institute, Mazandaran University of Medical \\ Sciences, Sari 481751665, Iran; heidarisomaye@yahoo.com (S.H.); s.seyedmousavi@gmail.com (S.S.) \\ 6 Department of Pathobiology, Faculty of Veterinary Medicine, Urmia University, Urmia 5756151818, Iran; \\ fatemekeramati6464@gmail.com \\ 7 Clinical Center, Microbiology Service, Department of Laboratory Medicine, National Institutes of Health, \\ Bethesda, MD 20892, USA \\ * Correspondence: kaboli2009@gmail.com (S.K.); jose.thekkiniath@fullerlabs.net (J.T.); \\ hedayatimt@gmail.com (M.T.H.)
}

check for updates

Citation: Nargesi, S.; Kaboli, S.; Thekkiniath, J.; Heidari, S.; Keramati, F.; Seyedmousavi, S.; Hedayati, M.T. Recent Advances in Genome Editing Tools in Medical Mycology Research. J. Fungi 2021, 7, 257. https:// doi.org/10.3390/jof7040257

Academic Editor: Willem Melchers

Received: 12 February 2021

Accepted: 25 March 2021

Published: 30 March 2021

Publisher's Note: MDPI stays neutral with regard to jurisdictional claims in published maps and institutional affiliations.

Copyright: (c) 2021 by the authors. Licensee MDPI, Basel, Switzerland. This article is an open access article distributed under the terms and conditions of the Creative Commons Attribution (CC BY) license (https:/ / creativecommons.org/licenses/by/ $4.0 /)$.

\begin{abstract}
Manipulating fungal genomes is an important tool to understand the function of target genes, pathobiology of fungal infections, virulence potential, and pathogenicity of medically important fungi, and to develop novel diagnostics and therapeutic targets. Here, we provide an overview of recent advances in genetic manipulation techniques used in the field of medical mycology. Fungi use several strategies to cope with stress and adapt themselves against environmental effectors. For instance, mutations in the 14 alpha-demethylase gene may result in azole resistance in Aspergillus fumigatus strains and shield them against fungicide's effects. Over the past few decades, several genome editing methods have been introduced for genetic manipulations in pathogenic fungi. Application of restriction enzymes to target and cut a double-stranded DNA in a pre-defined sequence was the first technique used for cloning in Aspergillus and Candida. Genome editing technologies, including zinc-finger nucleases (ZFNs) and transcriptional activator-like effector nucleases (TALENs), have been also used to engineer a double-stranded DNA molecule. As a result, TALENs were considered more practical to identify single nucleotide polymorphisms. Recently, Class 2 type II Clustered Regularly Interspaced Short Palindromic Repeat (CRISPR)/Cas9 technology has emerged as a more useful tool for genome manipulation in fungal research.
\end{abstract}

Keywords: gene editing techniques; CRISPR/Cas9; medically important fungi

\section{Introduction}

The fungi represent a large, diverse group of eukaryotic microorganisms that have a small genome size, short timeframes for growth and reproduction, and share homologous genes with humans [1]. Aspergillus, Candida, and Cryptococcus are the major fungal genera that cause opportunistic and life-threatening mycoses [2,3]. Over the past decades, genetic engineering has paved the way for the desired modifications by gene manipulation using a wide range of methods [4,5]. Genetic tools have been widely used to understand the virulence potential and pathobiology of fungal infections [6], as well as patterns of resistance development against antifungals [7]. Genome editing is a very useful tool which allows manipulation of a target site in a shorter period of time [8,9]. Here, we discuss the recent advances in genetic manipulation techniques that have been used in the field 
of medical mycology research with special emphasis on CRISPR/Cas9 technology. Additionally, we address the future perspectives of CRISPR/Cas9 applications in medically relevant fungi.

\section{Genome Editing Technologies}

Genome editingtechnology is a flexible engineering tool for genetic manipulation of microorganisms including fungi $[8,9]$.

\subsection{RNA Interference (RNAi)}

RNA interference (RNAi) is an RNA-mediated, sequence specific gene silencing mechanism involved in multiple biological processes, particularly in host defense and gene regulation $[10,11]$. RNAi is initiated by a RNAse III enzyme (Dicer) that cleaves a long double-stranded RNA (dsRNA) into double stranded 21-24 nucleotides small interfering RNAs (siRNAs). Each siRNA consists of a guide strand and passenger strand. As guide strand becomes part of an active RNA-induced silencing complex (RISC), the passenger strand is degraded by the following cellular events in the cytoplasm. The guide strand of the siRNA-RISC complex base-pairs with the complementary mRNA target sequences and initiates endonucleolytic cleavage by induced Argonaute protein (AGO; catalytic component of the RISC complex), which prevents translation of the target transcript (Figure 1). Different components of the fungal RNAi machinery not only play key roles in fungal growth and development, but also important in pathogenesis. In designing a single siRNA or an RNAi hairpin construct capable of producing a number of siRNAs specific for the target gene, it is important that the siRNA(s) targeting the mRNA must have a high efficiency of silencing as well as a low probability of binding to off-target mRNAs.

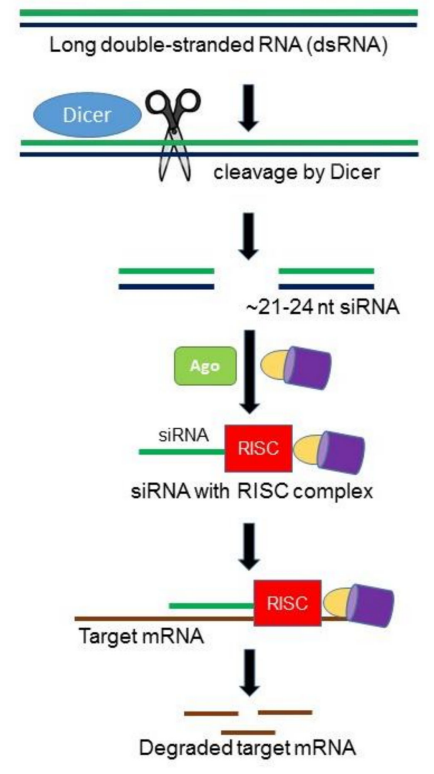

Figure 1. Hypothetical model of RNA interference (RNAi) pathway in fungi. The Dicer ribonuclease III enzyme (DCR) cleaves exogenous long double-stranded RNA (dsRNAs) into 21-24 nucleotide small interfering RNAs (siRNAs). The guide siRNA then loaded onto the major catalytic component called Argonaute (Ago) and other proteins generating the RNA-induced silencing complex (RISC). siRNA, along with RISC, complementarily pair with messenger RNA (mRNA) resulting in degradation of mRNAs.

Impact of RNAi on the cyp51A gene in the itraconazole-resistant Aspergillus fumigatus has shown that in addition to reducing the expression of the cyp51A gene, the minimum inhibitory concentration (MIC) of itraconazole has also decreased [12]. Previous studies showed that the deletion of ERG3 and ERG11 genes in C. albicans isolates induced increased 
azole sensitivity $[13,14]$. Moreover, deletion of these genes impaired the invasion of C. albicans into the oral mucosa [15]. Epigenetic pathways establish drug resistance in fungi by affecting a number of chromatin or RNA modifications. The changes caused by RNA are induced through small RNAs (sRNAs) and RNAi. A type of genetic mutation that contributes to resistance to rapamycin and FK506 has also been identified in Mucor circinelloides through RNAi pathway. Histone acetylation also activates the epigenetic machinery of chromatin. The acetylation process, which influences the nature of histone, has been shown to be one of the mechanisms of drug resistance in C. albicans [16,17]. Histone deacetylation-induced chromatin alteration was revealed as a function of HDAC genes which directly affects the virulence of the microorganism [18,19]. RNAi has been used as an important reverse genetics approach to understand gene function in fungi. It is inexpensive and enables us to carry out high-throughput interrogation of gene function [20,21]. However, one of the major disadvantages of RNAi is that it provides only temporary inhibition of gene function and unpredictable off-target effects [22].

\subsection{Restriction Enzymes}

Restriction enzymes are among the first generation of genome editing tools used in the field of medical mycology. These enzymes are designed to induce genome changes by cutting DNA molecules at defined points and inserting new genes at the cutting sites [23]. This mechanism of action of the restriction enzymes has made them a valuable method for cloning. However, the major issue with this method is that it is not easy to specify in advance where exactly the gene will be inserted, as the recognition sequences of most restriction enzymes are just a few base pairs long and often repeat several times in a genome. Moreover, the specificity of a restriction enzyme is dependent on environmental conditions. Since the discovery of restriction enzymes in the early 1970s, they have been widely used for the genetic manipulation of medically important fungi. Restriction enzyme mediated integration (REMI) has been employed to create mutants in medically relevant fungi including C. albicans, A. nidulans, and A. fumigatus [24,25]. However, it is important to note that in C. albicans, only heterozygous mutations are obtained. Aspergillus and Candida spp. are best examples of pathogenic fungi in which azole resistance mechanisms have been explored using the ability of restriction enzymes to provide a series of genetic patterns [26-28].

\subsection{Zinc-Finger Nucleases (ZFNs)}

Due to the mentioned limitations regarding restriction enzymes, scientists looked for ways of improving the precision of these enzymes and altering them so that they could distinguish a unique sequence in the genome. Zinc finger nucleases are examples of such unique sequences [29].

The efficiency of ZFNs as a gene editing tool is much more advanced than that of restriction enzymes. ZFN monomers are molecular proteins with two functional fused domains including the $\mathrm{C} 2 \mathrm{H} 2$ zinc-finger (ZF) DNA-binding domain, which targets three base pairs and a non-specific catalytic domain of the FokI endonuclease. The $\mathrm{C} 2 \mathrm{H} 2 \mathrm{ZF}$ domain is consisting of about 30 amino acids, two antiparallel $\beta$-sheets and an $\alpha$-helix, and a zinc ion coordinated by two cysteine residues in the $\beta$-sheets and two histidine residues in the $\alpha$-helix. FokI is a type IIS restriction enzyme involved in cleaving DNA at a distinct distance away from their recognition sites. To generate three-finger ZFs recognizing a 9-bp sequence in modular assembly, the user joins the appropriate ZF modules together. A DNA double-stranded cleavage requires dimerization of two FokI nuclease domains $[30,31]$. Although ZFN method was applied to gene editing in human cells and model organisms including Arabidopsis thaliana, Caenorhabditis elegans, and Drosophila, there have not been any studies done in fungi. 


\subsection{Transcription Activator-Like Effector Nucleases (TALENs)}

TALENs have emerged as an alternative genome editing tool to ZFNs and are similar to ZFNs in that they can cleave their double-stranded DNA target at any desired site. Fok1 nuclease is a common functional part between ZFNs and TALENs. However, designing TALENs is more straightforward than ZNFs. In TALEN-mediated gene editing process, TALEs bind their DNA at the desired site by arrays of highly conserved 33-35 amino acid repeats that are flanked by additional TALE-derived domains at the amino-terminal and carboxy-terminal ends of the array. Each TALE repeat is largely identical, except for two highly variable residues typically found at positions 12 and 13 of the domain, referred to as the repeat variable di-residues (RVDs). This structural difference has increased the detection coefficient in TALENs and has shown higher target binding specificity as compared to ZFNs. Thus, TALENs have the ability to identify single nucleotide polymorphisms (SNPs) [32,33].

\subsection{Clustered Regularly Interspaced Short Palindromic Repeats (CRISPR)-CRISPR Associated Protein 9 (CRISPR-Cas9)}

The CRISPR (Clustered Regularly Interspaced Short Palindromic Repeats)/CRISPRassociated protein 9 (Cas9) is an adaptive immunity system in bacteria and was initially used for genome editing in mammalian and yeast cells [34-36]. Gradually it has become a revolutionary tool in molecular biology and biotechnology that enables us to perform precise genomic, epigenomic, RNA editing, gene expression regulation, nucleic acid detection, and several applications in a wide variety of organisms [36-44]. Currently, delivery of the CRISPR system's components into fungal cells through different types of vectors and assembled purified sgRNA/Cas9 complexes have enabled us to mutate the genome or alter gene expression regulation in dozens of fungal species [36,45-48]. Alternatively, cell-penetrating peptides have been shown to be able to enter into Candida spp. [49,50]. These CRISPR-empowered enhancements have been considered a scientific breakthrough in fungal molecular biology and biotechnology [51], and stem from its versatile potential to functional characterization and breeding of clinically and industrially important fungi.

\section{Mechanism of Action of CRISPR-Cas9}

The type II CRISPR-Cas system (CRISPR-Cas9 from Streptococcus pyogenes) consists of two key molecules, including the Cas9 DNA endonuclease and a small chimeric protospacer adjacent motif (PAM) - dependent guide RNA (sgRNA). The sgRNA is composed of CRISPR RNA (crRNA) and trans-activating crRNA (tracrRNA) [45], The Cas operon encodes Cas1, Cas2, and Cas9 signature proteins, and sometimes a fourth protein (Csn2 or Cas4). Moreover, repeat-spacer array alternatively contains repeats and unique spacers [52,53]. The CRISPR-array initially transcribes a precursor-CRISPR RNA (pre-crRNA), which is then processed and matured by trans-activating crRNA (tracrRNA) and RNaseIII. TracrRNA is a partial complement to a repeating sequence of crRNA, forming the chimeric sgRNA, which subsequently directs the Cas9 protein to the cleavage site. The spacer sequence of crRNA is also complementary to target DNA, such as viral nucleic acids. Then, the multifunctional and multidomain protein, Cas9, in complex with 20-nucleotide (nt) of sgRNA, cleaves both strands of target DNA preceding to protospacer adjacent motif (PAM) [54,55]. The native PAM sequence used by Cas9 is $5^{\prime}$ NGG $3^{\prime}$, followed by a downstream crRNA complementary sequence that is crucial for discrimination of host and foreign nucleic acid $[55,56]$. The cleavage of target strand hybridizing to guide RNA and non-target strand is performed by HNH and RUVC domains of this endonuclease, respectively. Then, this fragment integrates in the CRISPR locus, allowing it to act as a new spacer sequence. Cells can detect and clear invading DNA during subsequent infection of the similar invader. This system can be effectively programmed by modifying the sequence of sgRNA to trigger desired nucleic acid cleavage. Nuclease-induced double strand breaks can be repaired by either error-prone non-homologous end joining (NHEJ) or homology directed repair (HDR) [56]. The high-fidelity HDR pathway serves as a precise 
gene modification by homologous recombination between donor template and repair DNA, whereas the latter leads to variable nucleotides insertion or deletion, eventually results in several mutations [56]. Figure 2 shows the schematic representation of RNA-guided Cas 9 constructs designed for genome editing.

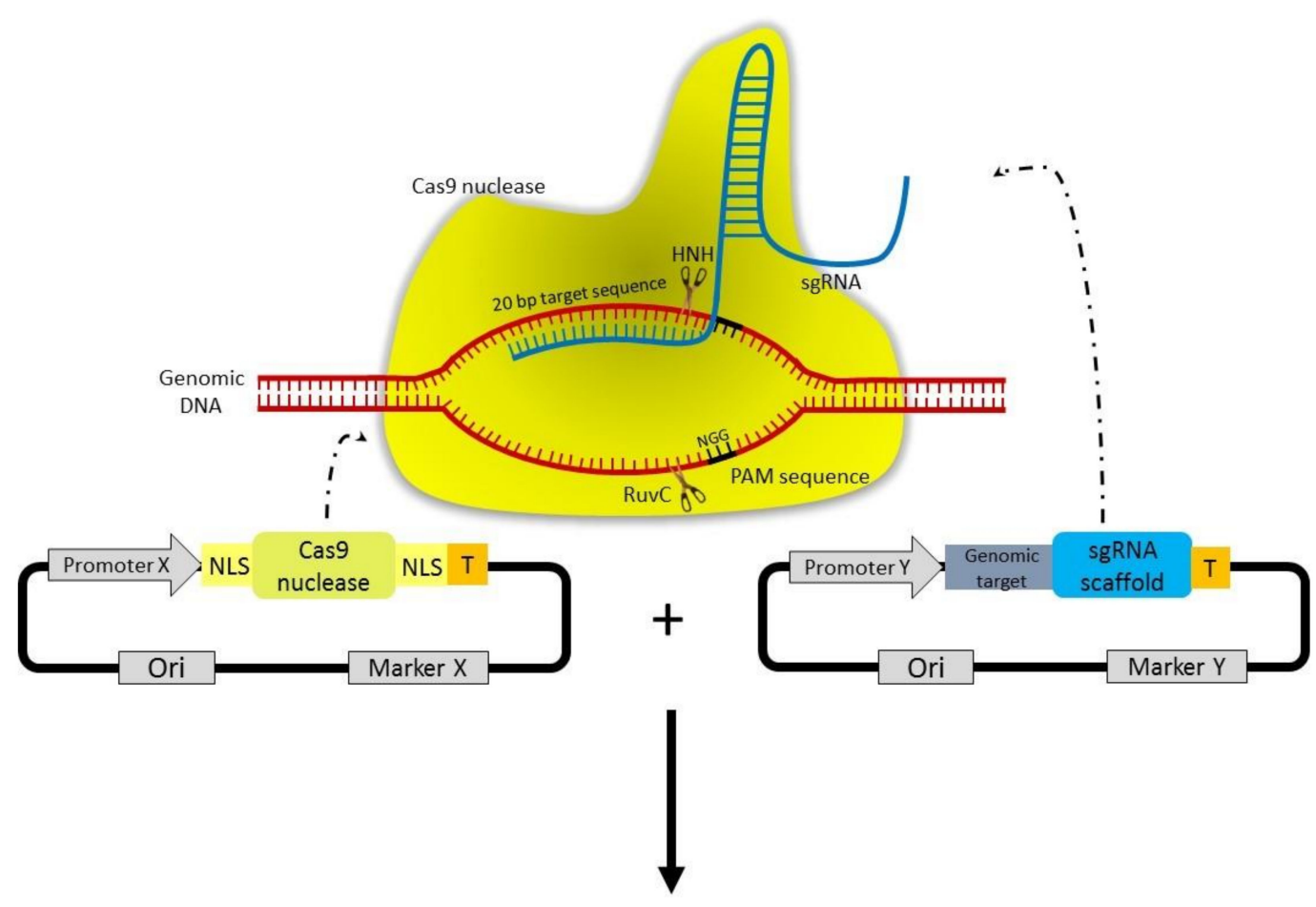

\section{Knockout/Insertion/Single-base mutation, etc.}

Figure 2. Schematic representation of RNA-guided Cas9 constructs designed for genome editing. Bottom panel: (structure of the vector plasmids used to deliver Cas9-sgRNA components into fungal cells). PromoterX can express NLS-Cas9-NLS protein. PromoterY can express $20 \mathrm{nt}$ guide sequence + sgRNA cassette. Upper panel: (Cas9+sgRNA+genomic DNA). Mechanism of Cas9/gRNA ribonucleoprotein complex action, NGG (PAM site) highlighted in black line. The Cas9 nuclease domain $\mathrm{HNH}$ then cleaves the target DNA sequence complementary to the 20 bp guide sequence, while RuvC domain cuts another DNA strand, forming a double stranded break (DSB). DSB must be repaired via either non-homologous end joining (NHEJ) or homologous recombination (HR) immediately to avoid cell death. Insertions and deletion mutations at the target site generated by NHEJ and homology directed repair (HDR) allow disrupting or abolishing the function of a target gene. Moreover, modifications in this system can also be used to silence genes, insert new exogenous DNA, or block RNA transcription.

\section{Applications of CRISPR-Cas9 Genome Editing Tool in Medically Important Fungi}

\subsection{Clinically Relevant Yeasts}

Candida spp. are challenging for the molecular geneticist; the genome engineering and drug development against Candidiasis has been difficult for several years. Vyas and colleagues were the first to develop the CRISPR/Cas9 system in C. albicans [57]. Using this system, homozygous gene knock-out and multiple gene mutation have been successfully created in this fungus. Efforts to improve CRISPR-mediated genome editing have been developed in other Candida spp. Recently, Nguyen and colleagues reported a rapid and efficient edition without performing a molecular cloning step and utilizing permanent markers in the engineering location [58].

Since then, the CRISPR system has been utilized in several Candida spp. [59-68]. Therefore, CRISPR-based single and multiple gene knock-out libraries would be possible in these fungi, which further help us to develop new antifungal drugs. Cryptococcosis 
is a life-threatening fungal disease caused by Cryptococcus neoformans and Cryptococcus gattii. Cryptotoccocus spp. are found in soils contaminated with bird droppings, and in association with rotting vegetation, including eucalyptus tree hollows [69]. The prevalence of Cryptococcosis has been increasing over the past years for many reasons, including worldwide prevalence of AIDS and the expanded use of immunosuppressive drugs. Although the most common presentation of Cryptococcosis is of $C$. neoformans infection in immunocompromised people, $C$. gattii is being increasingly recognized as a pathogen in immunocompetent hosts [70]. There is an urgent need to use the CRISPR system in Cryptococcus spp. because low rates of homologous integration have hindered molecular genetic studies in these fungi. This limitation has been a major obstacle for the diagnosis and treatment of deadly Cryptococcal disease. Recently, the CRISPR/Cas9 system has been developed to stimulate homologous recombination (HR) for gene alteration in C. neoformans [71-76]. Taken together, CRISPR constructs can be successfully used for gene editing in Cryptococcus spp. and thus the CRISPR system would be a promising tool for drug discovery against Cryptococcosis. Strategies and applications of the CRISPR/Cas system in medically important yeasts are shown in Table 1.

Table 1. Modules, applications and success rate of the CRISPR/Cas9 system in manipulating clinically relevant yeasts.

\begin{tabular}{|c|c|c|c|c|c|c|}
\hline Organism & $\begin{array}{c}\text { CAS9 Expression } \\
\text { Module }\end{array}$ & $\begin{array}{c}\text { GRNA } \\
\text { Expression } \\
\text { Module }\end{array}$ & Target Gene (S) & $\begin{array}{l}\text { Purpose of } \\
\text { Application }\end{array}$ & $\begin{array}{c}\text { Editing Rate and } \\
\text { Result }\end{array}$ & References \\
\hline C. albicans & $\begin{array}{c}\text { Candida/Saccharomyces } \\
\text { codon-optimized } \\
\text { version of Cas9 } \\
\text { (CaCas9)/the ENO1 } \\
\text { promoter }\end{array}$ & $\begin{array}{c}\text { The RNA } \\
\text { polymerase III } \\
\text { (Pol III) promoter } \\
\text { SNR52 }\end{array}$ & $\begin{array}{c}A D E 2, \\
C D R 1 / C D R 2\end{array}$ & $\begin{array}{l}\text { To generate } \\
\text { homozygous } \\
\text { mutations in one } \\
\text { transformation by } \\
\text { Duet and Solo } \\
\text { system }\end{array}$ & $\begin{array}{l}\text { Duet system } \\
\text { showed } 20-40 \% \\
\text { mutagenesis } \\
\text { efficiency, and } \\
\text { Solo system } \\
\text { enabled } 60-80 \% \\
\text { targeting }\end{array}$ & $\begin{array}{l}\text { Vyas et al. } \\
(2015) \text { [57] }\end{array}$ \\
\hline C. albicans & $\begin{array}{c}\text { Transient } \\
\text { CRISPR-Cas9 system } \\
\text { by using a SAT1-FLP } \\
\text { system }\end{array}$ & SNR52P/TENO1 & $\begin{array}{l}\text { NDT80, REP1, } \\
\text { and RON1 }\end{array}$ & $\begin{array}{c}\text { To better } \\
\text { understand role } \\
\text { of target genes } \\
\text { (single or in } \\
\text { combination) in } \\
\text { virulence }\end{array}$ & $\begin{array}{l}\text { Single, double, } \\
\text { and triple } \\
\text { deletion strains } \\
\text { were successfully } \\
\text { constructed }\end{array}$ & $\begin{array}{c}\text { Min et al. (2018) } \\
\text { [60] }\end{array}$ \\
\hline C. albicans & $\begin{array}{l}\text { US-pENO1 } \\
>\text { Cas9-NAT }\end{array}$ & $\begin{array}{l}\text { NAT-pSNR52- } \\
\text { gRNA-DS }\end{array}$ & $\begin{array}{c}\text { ADE2, URA3, } \\
\text { WOR1,WOR, and } \\
\text { CZF1 }\end{array}$ & $\begin{array}{c}\text { To develop a } \\
\text { marker less } \\
\text { system without } \\
\text { need for } \\
\text { molecular cloning } \\
\text { step }\end{array}$ & $\begin{array}{l}80 \% \text { single gene } \\
\text { deletion, } 20 \% \\
\text { double genes } \\
\text { deletion and } \\
>50 \% \text { integration } \\
\text { efficiency }\end{array}$ & $\begin{array}{l}\text { Nguyen et al. } \\
\text { (2017) [58] }\end{array}$ \\
\hline C. albicans & $\begin{array}{c}\text { CIp-ARG4-PTEF } \\
\text { CaCAS9 }\end{array}$ & $\begin{array}{l}\text { PADH1-tRNA- } \\
\text { driven gRNA } \\
\text { expression }\end{array}$ & $R F P$ & $\begin{array}{l}\text { To optimize } \\
\text { gRNA } \\
\text { intracellular } \\
\text { expression }\end{array}$ & $\begin{array}{l}\text { Increase the gene } \\
\text { editing efficiency } \\
\text { by } 10 \text {-fold }\end{array}$ & $\begin{array}{c}\text { Ng et al. (2017) } \\
{[64]}\end{array}$ \\
\hline C. albicans & $\begin{array}{l}\text { CaCas9 into the } C \text {. } \\
\text { albicans genome at the } \\
\text { NEUT5L locus }\end{array}$ & $\begin{array}{c}5^{\prime} \text { homology } \\
\text { arm-SNR52 } \\
\text { promoter- } \\
\text { gRNA1-gRNA2- } \\
\text { 3' homology } \\
\text { arm }\end{array}$ & $\begin{array}{l}\text { antifungal efflux } \\
\text { and biofilm } \\
\text { adhesion factors }\end{array}$ & $\begin{array}{l}\text { To develop a gene } \\
\text { drive array } \\
\text { system for the } \\
\text { generation of } \\
\text { combinatorial } \\
\text { deletion mutants }\end{array}$ & $\begin{array}{l}\text { Two larges } \\
\text { pairwise gene } \\
\text { deletion mutants } \\
\text { were successfully } \\
\text { generated }\end{array}$ & $\begin{array}{l}\text { Shapiro et al. } \\
\text { (2018) [63] }\end{array}$ \\
\hline C. albicans & $\begin{array}{l}\text { the ENO1 } \\
\text { promoter/Cas9 } \\
\text { (CaCas9)/T } \mathrm{T}_{\mathrm{CYC} 1}\end{array}$ & SNR52P/T $\mathrm{TNO}_{\mathrm{EN}}$ & $A D E 2$ & $\begin{array}{l}\text { To describe a } \\
\text { transient } \\
\text { CRISPR-Cas9 } \\
\text { system for } \\
\text { efficient gene } \\
\text { deletion }\end{array}$ & $\begin{array}{c}\text { Homozygous } \\
\text { deletions by } \\
\text { introduction of } \\
\text { CaCas9 } \\
\text { transiently }\end{array}$ & $\begin{array}{c}\text { Min et al. (2016) } \\
\text { [59] }\end{array}$ \\
\hline
\end{tabular}


Table 1. Cont.

\begin{tabular}{|c|c|c|c|c|c|c|}
\hline C. parapsilosis & TEF1p-CAS9-TEF1t & $\begin{array}{c}\text { pCpSNR52- } \\
\text { sgRNA-SUP4t } \\
\text { and cpGAPDHp- } \\
\text { HH-sgRNA- } \\
\text { HDV-GAPDHt }\end{array}$ & $\begin{array}{c}\text { ADE2, } \\
\text { CPAR2_101060 } \\
\text { and URA3 }\end{array}$ & $\begin{array}{l}\text { To apply gene } \\
\text { manipulation in } \\
\text { single } \\
\text { transformation } \\
\text { step which can be } \\
\text { used for editing } \\
\text { of any number of } \\
\text { target genes }\end{array}$ & $\begin{array}{l}\text { The system } \\
\text { yielded up to } \\
100 \% \text { efficiency } \\
\text { across a panel of } \\
20 \text { clinical isolates }\end{array}$ & $\begin{array}{l}\text { Lombardi et al. } \\
\text { (2017) [66] }\end{array}$ \\
\hline C. glabrata & $\begin{array}{c}\text { pTEF1-Cas9- } \\
\text { tCYC1/pCYC1-Cas9- } \\
\text { tCYC1 }\end{array}$ & $\begin{array}{l}\text { pSNR52-sgRNA- } \\
\text { tTY2/pRNAH1- } \\
\text { sgRNA-tTY2 }\end{array}$ & $\begin{array}{c}\text { ADE2, VPK1 and } \\
\text { YPS11 }\end{array}$ & $\begin{array}{l}\text { To establish a } \\
\text { loss-of-function } \\
\text { mutation through } \\
\text { the NHEJ repair } \\
\text { pathway }\end{array}$ & High & $\begin{array}{l}\text { Enkler et al. } \\
\text { (2016) [61] }\end{array}$ \\
\hline C. glabrata & pTEF-Cas9-KanMX & $\begin{array}{l}\text { pSNR52-sgRNA- } \\
\text { CYC1t }\end{array}$ & $\begin{array}{l}A D E 2, M E T 15 \\
\text { and SOK2 }\end{array}$ & $\begin{array}{l}\text { To compare } \\
\text { genome } \\
\text { modifications in } \\
\text { C. glabrata wild } \\
\text { type and lig4 } \\
\text { strains }\end{array}$ & $\begin{array}{l}\text { Targeting } \\
\text { efficiency in the } \\
\text { lig } 4 \Delta \text { mutant was } \\
\text { higher than in the } \\
\text { wild type strain }\end{array}$ & $\begin{array}{c}\text { Cen et al. (2017) } \\
\text { [62] }\end{array}$ \\
\hline C. albicans & $\begin{array}{l}\text { Codon-optimized } \\
\text { version of } \\
\text { Cas9(CaCas9)- } \\
\text { SV40NLS }\end{array}$ & $\begin{array}{l}\text { SNR52 RNA } \\
\text { polymerase III } \\
\text { promoter }\end{array}$ & $C D R 1$ and $C D R 2$ & $\begin{array}{l}\text { To present a } \\
\text { modified } \\
\text { gene-drive-based } \\
\text { assay for gene } \\
\text { manipulation }\end{array}$ & - & $\begin{array}{l}\text { Halder et al. } \\
\text { (2019) [65] }\end{array}$ \\
\hline C. albicans & $\begin{array}{c}\text { ACT1p-dCAS9- } \\
\text { ACT1t }\end{array}$ & $\begin{array}{l}\text { SNR52p-gRNA } \\
\text { tail }\end{array}$ & $A D E 2$ & $\begin{array}{l}\text { To demonstrate a } \\
\text { functional } \\
\text { CRISPRi system } \\
\text { for transcriptional } \\
\text { repression }\end{array}$ & $\begin{array}{l}\text { 20-fold repression } \\
\text { of target gene } \\
\text { achieved }\end{array}$ & $\begin{array}{l}\text { Wensing et al. } \\
\text { (2019) [68] }\end{array}$ \\
\hline $\begin{array}{l}\text { C. parapsilosis, } \\
\text { C. } \\
\text { orthopsilosis, } \\
\text { C. metapsilosis } \\
\text { and C. } \\
\text { tropicalis }\end{array}$ & $\begin{array}{l}\text { MgTEF1p-CAS9- } \\
\text { MgTRP1t }\end{array}$ & $\begin{array}{l}\text { pAgTEF1- } \\
\text { sgRNA-HDV- } \\
\text { ScCYC1t }\end{array}$ & $\begin{array}{c}\text { ADE2 and } \\
\text { CPAR2_101060 }\end{array}$ & $\begin{array}{l}\text { To construct an } \\
\text { autonomously } \\
\text { replicating } \\
\text { plasmid for } \\
\text { markerless ediing } \\
\text { in Candida spp. }\end{array}$ & $\begin{array}{c}\text { Single gene } \\
\text { distribution } \\
\text { efficiency } \\
\text { observed in C. } \\
\text { parapsilosis } \\
\text { (approximately } \\
80 \% \text { ), C. meta } \\
\text { psilosis (100\%), C. } \\
\text { tropicalis } \\
(88-100 \%)\end{array}$ & $\begin{array}{l}\text { Lombardi et al. } \\
\text { (2019) [67] }\end{array}$ \\
\hline $\begin{array}{l}\text { Cryptococcus } \\
\text { neoformance }\end{array}$ & $\begin{array}{l}\text { TEF1p-Cas9- } \\
\text { SV40NLS-TEF1t }\end{array}$ & $\begin{array}{l}\text { pACT1-HH- } \\
\text { gRNA-HDV- } \\
\text { TRPt }\end{array}$ & $A D E 2$ & $\begin{array}{l}\text { To demonstrate } \\
\text { the first proof of } \\
\text { principle study }\end{array}$ & $70 \%$ & $\begin{array}{l}\text { Arras et al. } \\
\text { (2016) [71] }\end{array}$ \\
\hline C. neoformans & $\begin{array}{l}\text { ACT1P-SV40NLS- } \\
\text { Cas9-NLS-bGHpAt }\end{array}$ & $\begin{array}{l}\text { pCnU6-GN19- } \\
\text { gRNA-6Ts }\end{array}$ & $A D E 2$ and Tsp2-1 & $\begin{array}{l}\text { To develop a } \\
\text { system for gene } \\
\text { alterations by } \\
\text { subsequent } \\
\text { complementation } \\
\text { and off-target } \\
\text { effects reduction }\end{array}$ & $\begin{array}{c}\text { Frequency of } \\
\text { gene deletion was } \\
\text { over } 80 \% \text {, indel } \\
\text { efficiency and HR } \\
\text { rates were } 40-90 \% \\
\text { and } 20-90 \% \text {, } \\
\text { respectively }\end{array}$ & $\begin{array}{l}\text { Wang et al. } \\
\text { (2016) [72] }\end{array}$ \\
\hline C. neoformans & GPD1p-Cas9-GPD1 t & $\begin{array}{c}\text { pCnU6-sgRNA-6- } \\
\mathrm{Tt}\end{array}$ & $A D E 2$ & $\begin{array}{l}\text { To generate a } \\
\text { TRACE system as } \\
\text { an cost-effective } \\
\text { and efficient } \\
\text { strategy for } \\
\text { genetic } \\
\text { modifications }\end{array}$ & $\begin{array}{l}\text { Up to } 90 \% \text { gene } \\
\text { disruption rate }\end{array}$ & $\begin{array}{c}\text { Fan et al. (2018) } \\
\text { [73] }\end{array}$ \\
\hline C. neoformans & $\begin{array}{c}\text { pTEF-Cas9-FLAG- } \\
\text { NLS }\end{array}$ & $\begin{array}{l}\text { ptRNA-sgRNA- } \\
\text { NLS }\end{array}$ & GIB2 & $\begin{array}{c}\text { To deliver a } \\
\text { preassembled } \\
\text { RNP via } \\
\text { electroporation to } \\
\text { accelerate of gene } \\
\text { editing }\end{array}$ & $\begin{array}{l}\text { Approach is } \\
\text { sufficient to } \\
\text { induce gene } \\
\text { modification }\end{array}$ & $\begin{array}{l}\text { Wang P. (2018) } \\
{[74]}\end{array}$ \\
\hline
\end{tabular}




\subsection{Filamentous Fungi}

Although filamentous fungi are well-known for producing high-value substances and metabolites including drugs, they have increasingly been problematic by causing life-threatening human infections [75-80]. Therefore, exploiting their genome function through applying precise and efficient techniques, thereby preventing the fungal infections, is critical. Regardless of benefit or health risks, genetic tools have not been well developed in filamentous fungi. It has been shown that polyketide synthase (PKS) is a crucial enzyme needed for toxin biosynthesis in filamentous fungi [81] and its disruption yields to engineered fungi with significant reduction in their detrimental effect to its host [82]. As a proof of principle, in a study by Fuller and colleagues, PKS in A. fumigatus was targeted for loss-of-function study using the CRISPR system [83]. They found high editing efficiency $(25-53 \%)$ and demonstrated that the constitutive expression of Cas9 is not deleterious to A. fumigatus growth and other features. Additionally, Cas9-hph strain was constructed to be used as a universal recipient of sgRNA in CRISPR-based engineering. Since then, to enhance efficiency rates, in-frame integration with or without marker insertion with approximately $95-100 \%$ accuracy assisted by microhomology-mediated end joining (MMEJ) has been developed in A. fumigatus [84]. The genetic alteration via the CRISPR/Cas9 system has been effectively developed in A. fumigatus to determine the importance of various genes in Aspergillus [46-48]. For instance, the CRISPR has been applied by Umeyama and colleagues to replace cyp $51 A$ gene in azole-resistant clinical $A$. fumigatus isolates [46]. In this study, ribonucleoprotein complex of Cas9/gRNA and donor template have been simultaneously delivered into cells followed by testing azole susceptibility in transformants, which showed increased susceptibility via the replacement of Ser138 by glycine [46]. These studies demonstrated high performance of CRISPR/Cas9 system in Aspergillus research together with diversity in usability of systems components. Recently, a CRISPR-based plasmid free approach (a Cas9 RNP-mediated method) targeted for carB and $h m g R 2$ genes of Mucor circinelloides resulted in stable gene disruption mutants [85]. To investigate molecular pathogenesis mechanisms of Rhizopus delemar, single nucleotide (nt) deletions in two clinical strains FGSC-9543 and CDC-8219 were carried out [86]. Taken together, these data indicate that these approaches are simple and reliable and can be adapted in other filamentous fungi as well. Strategies and applications of CRISPR/Cas9 system in medically important filamentous fungi are shown in Table 2.

Table 2. Modules, applications and success rate of the CRISPR system in manipulating clinically relevant molds.

\begin{tabular}{|c|c|c|c|c|c|c|}
\hline Organism & $\begin{array}{c}\text { CAS9 Expression } \\
\text { Module }\end{array}$ & $\begin{array}{c}\text { GRNA } \\
\text { Expression } \\
\text { Module }\end{array}$ & $\begin{array}{l}\text { Target Gene } \\
\text { (S) }\end{array}$ & $\begin{array}{l}\text { Purpose of } \\
\text { Application }\end{array}$ & $\begin{array}{c}\text { Editing Rate and } \\
\text { Result }\end{array}$ & References \\
\hline A. fumigatus & p-hph-Ptef1-cas9 & $\begin{array}{l}\text { p426-SNR52p- } \\
\text { gRNA.CAN1.Y- } \\
\text { SUP4t }\end{array}$ & $P K S P$ & $\begin{array}{c}\text { To test CRISPR-CAS9 } \\
\text { method in this } \\
\text { organism }\end{array}$ & $\begin{array}{l}\text { High gene targeting } \\
\text { efficiency reached } \\
25-53 \%\end{array}$ & $\begin{array}{l}\text { Fuller et al. } \\
(2015) \text { [83] }\end{array}$ \\
\hline A. fumigatus & $\begin{array}{c}\text { Gpdap-3xFLAG- } \\
\text { NLS-Cas9-NLS- } \\
\text { TRPCt }\end{array}$ & U6-3-gRNA & $\begin{array}{c}\text { pksP and cnaA } \\
\text { genes }\end{array}$ & $\begin{array}{l}\text { To establish the } \\
\text { system for } \\
\text { mutagenesis using } \\
\text { MMEJ process }\end{array}$ & $\begin{array}{c}\text { Approximately } \\
95-100 \% \text { rate of } \\
\text { mutagenesis } \\
\text { obtained }\end{array}$ & $\begin{array}{l}\text { Zhang et al. } \\
\text { (2016) [84] }\end{array}$ \\
\hline A. fumigatus & $\begin{array}{l}\text { Alt-R-CRISPR- } \\
\text { Cas9 components } \\
\text { from integrated } \\
\text { DNA } \\
\text { technologies } \\
\text { (IDT) }\end{array}$ & $\begin{array}{c}\text { cr5 }=\text { pksP and } \\
\text { cr3 = pksP }\end{array}$ & $P K S P$ & $\begin{array}{l}\text { An in vitro assembly } \\
\text { of RNP demonstrated } \\
\text { to eliminate the strain } \\
\text { construction step }\end{array}$ & $\begin{array}{c}\text { Gene deletion } \\
\text { efficiency was close } \\
\text { to } 100 \%\end{array}$ & $\begin{array}{l}\text { Al-Abdallah } \\
\text { et al. (2017) [48] }\end{array}$ \\
\hline A. fumigatus & Cas9-NLS & T7-sgRNA & CYP51A & $\begin{array}{l}\text { To investigate the } \\
\text { mechanisms of azole } \\
\text { resistance via cyp51A } \\
\text { alteration }\end{array}$ & $\begin{array}{l}\text { Site-directed } \\
\text { mutagenesis } \\
\text { successfully } \\
\text { performed using } \\
\text { CRISPR-CAS9 } \\
\text { system }\end{array}$ & $\begin{array}{l}\text { Umeyama et al. } \\
\text { (2018) [46] }\end{array}$ \\
\hline
\end{tabular}


Table 2. Cont.

\begin{tabular}{|c|c|c|c|c|c|c|}
\hline Organism & $\begin{array}{l}\text { CAS9 Expression } \\
\text { Module }\end{array}$ & $\begin{array}{l}\text { GRNA } \\
\text { Expression } \\
\text { Module }\end{array}$ & $\begin{array}{l}\text { Target Gene } \\
\text { (S) }\end{array}$ & $\begin{array}{c}\text { Purpose of } \\
\text { Application }\end{array}$ & $\begin{array}{c}\text { Editing Rate and } \\
\text { Result }\end{array}$ & References \\
\hline $\begin{array}{c}\text { Mucor } \\
\text { circinelloides }\end{array}$ & $\begin{array}{c}\text { Alt-R } \\
\text { CRISPR-Cas9 } \\
\text { tracrRNA }\end{array}$ & $\begin{array}{l}\text { Alt-R CRISPR } \\
\text { crRNA }\end{array}$ & $\begin{array}{l}\text { CARB and } \\
\text { HMGR2 }\end{array}$ & $\begin{array}{c}\text { To obtain mitotically } \\
\text { stable mutants, a } \\
\text { plasmid free } \\
\text { CRISPR-Cas9 } \\
\text { approach } \\
\text { demonstrated }\end{array}$ & $\begin{array}{l}\text { Targeting efficiency } \\
\text { of NHEJ and HR } \\
\text { reach to } 100 \%\end{array}$ & $\begin{array}{l}\text { Nagy et al. } \\
\text { (2017) [85] }\end{array}$ \\
\hline $\begin{array}{l}\text { Rhizopus } \\
\text { delemar }\end{array}$ & $\begin{array}{c}\text { pmCas9: } \\
\text { tRNA-gRNA }\end{array}$ & $\begin{array}{c}\text { pmCas9: } \\
\text { tRNA-gRNA }\end{array}$ & PYRF & $\begin{array}{c}\text { For investigating } \\
\text { molecular } \\
\text { pathogenesis } \\
\text { mechanisms, point } \\
\text { mutation introduced }\end{array}$ & $\begin{array}{c}\text { Efficiency of } 36 \% \text { to } \\
59 \%\end{array}$ & $\begin{array}{l}\text { Bruni et al. } \\
\text { (2019) [86] }\end{array}$ \\
\hline
\end{tabular}

\section{Conclusions and Future Prospects}

Genetic engineering in many pathogenic fungi has been advanced in recent years and smooths the way for successful developments in the field of fungal genetics and molecular biology.

ZFNs and TALENS are useful technologies, as they facilitate researchers to create permanent mutations by introducing double-stranded breaks to activate repair pathways. However, these strategies are expensive and time-consuming to engineer, especially in large scale, high-throughput studies. A major advantage of RNAi is that a gene silencing and actual knockdown of gene expression is very simple. Unlike CRISPRi, RNAi does not target TSSs and also targets RNA transcripts in the cells' cytoplasm and not genomic DNA in the nucleus $[87,88]$. However, in contrast to Cas9 and TALE systems, irreversible knockout experiments are not possible using RNAi experiment. In comparison with RNAi, studies show stronger loss-of-function phenotypes with low off-targeting effects when using CRISPRi [88]. Therefore, only from the view point of ease of use in some experiments could RNAi be ahead of CRISPRi-based technologies.

Among the various technologies, CRISPR-based techniques permit a simpler design process, and more affordable and faster execution than engineered nuclease platforms, making them highly favorable engineering tools for industrially important microorganisms with limited availability of genetic tools. The information presented in this review suggests that the CRISPR-Cas9 technique has been successfully established for several human pathogenic fungi.

For generating more than 100 mutated strains, different approaches with edition efficiencies from too low to $100 \%$ have been used, and in most cases the application of the technique consisted of a proof of concept of its feasibility. Depending on the efficiency of homologous recombination and fungal intrinsic identity, CRISPR-based genome edition may vary from a simple single gene mutation to a complex multi-gene expression regulation. Regardless of the purpose of the study, efficiency of the system might be improved through targeted change on plasmid or donor DNA [47-49,89]. Employment of NHEJ mutant strains was shown to be indispensable for enhancing efficiency of homologous recombination in some studies $[69,90]$. However, marker-less gene deletion strain construction using transient expression plasmids that can self-replicate only under antibiotic pressure is an advantage [59,91-96].

Multiplexing properties of the CRISPR system [97-106] can accelerate its ability in many aspects in the future. For instance, in development of fungal cell factories for the production of added value metabolites [107] or in development of new antifungal bioactive compounds [108], the system can be an affordable facilitator tool through approaches like genome reduction to overrule unwanted products [109] and constructing sets of deletion mutants over fungal gene interaction networks [110], respectively. A catalytically dead version of Cas9 (dCas9) has been developed by adding two point mutations in Cas9 [52], 
and as an extension of its application, transcriptional reprogramming [111,112] for regulation of gene expression has been introduced. These approaches might be attractive tools for gene regulation in filamentous fungi that lack components of RNAi machinery as well as in multinucleated fungi. Speed, accuracy, and sensitivity in diagnosis are critical components for cost-effective detection of fungi, subsequent prevention, and treatment of fungal infections $[113,114]$. Current methods of diagnosis of fungal infections are time consuming and include an expensive process of phenotypic and biochemical approaches. Thus, a demand for modern molecular diagnostic methods like genomic imaging with Cas9 has been increased. Although the CRISPR/Cas9 technique has become an increasingly important tool for several applications in line of fungal research, off-target effect, especially when using multiple sgRNAs can still limit applications of CRISPR-Cas9 system. It is worth noting that CRISPR is not the latest genome manipulation technology. Prime editing is the newest class of known gene editing methods that has been introduced in the field of biotechnology since 2019. Prime editing, which can be used in biological systems, first searches for the points in the gene that need to be modified, then impose the editing effects, without breaking into double stranded DNA at the target points, through base deletion, insertion, and substitutions. The most notable advantage of this method to CRISPR is that it has less off-target effects and is more precise [115-117]. This technique is still in its infancy and has not yet been used in pathogenic fungi.

Author Contributions: S.K. and M.T.H. contributed to conceptualization. S.N. and S.H. wrote the first draft. S.K., S.S., J.T., F.K. and M.T.H. contributed to reviewing and revising the manuscript. All authors have read and agreed to the published version of the manuscript.

Funding: This research received no external funding. S.S was supported by a research fund from Intramural Research Program of the National Institutes of Health, Clinical Center, Department of Laboratory Medicine.

Institutional Review Board Statement: Not applicable.

Informed Consent Statement: Not applicable.

Data Availability Statement: Not applicable.

Conflicts of Interest: The authors report no conflicts of interest related to this manuscript. The authors alone are responsible for the content and writing of the paper.

\begin{tabular}{|c|c|}
\hline Ago & Argonaute \\
\hline AIDS & acquired immunodeficiency syndrome \\
\hline CRISPR & clustered regularly interspaced short palindromic repeats \\
\hline CRISPR-Cas9 & clustered regularly interspaced short palindromic repeats associated protein 9 \\
\hline Cas9-NLS & cas9 with a nuclear localization signal \\
\hline crRNA & CRISPR RNA \\
\hline dCas9 & dead version of Cas9 \\
\hline DSB & double stranded break \\
\hline dsRNA & double-stranded RNA \\
\hline HR & homologous recombination \\
\hline HDR & homology directed repair \\
\hline IDT & integrated DNA technologies \\
\hline MIC & minimum inhibitory concentration \\
\hline mRNA & messenger RNA \\
\hline NHEJ & non-homologous end joining \\
\hline NGG & nucleotide- guanine-guanine \\
\hline PAM & protospacer adjacent motif \\
\hline PKS & polyketide synthase \\
\hline
\end{tabular}




$\begin{array}{ll}\text { REMI } & \text { restriction enzyme mediated integration } \\ \text { RISC } & \text { RNA- induced silencing complex } \\ \text { RVD } & \text { repeat variable di-residues } \\ \text { SAT1-FLP } & \text { SAT1 flipper } \\ \text { SiRNA } & \text { small interfering RNA } \\ \text { sgRNA } & \text { single guide RNA } \\ \text { SNP } & \text { single nucleotide polymorphism } \\ \text { TALEN } & \text { transcription activator-like effector nucleases } \\ \text { tracrRNA } & \text { trans-activating crRNA } \\ \text { ZFN } & \text { zinc-finger nuclease }\end{array}$

\section{References}

1. Lin, X.; Alspaugh, J.A.; Liu, H.; Harris, S. Fungal Morphogenesis. Cold Spring Harb. Perspect. Med. 2014, 5, a019679. [CrossRef]

2. Schmiedel, Y.; Zimmerli, S. Common invasive fungal diseases: An overview of invasive candidiasis, aspergillosis, cryptococcosis and Pneumocystis pneumonia. Swiss Med. Wkly. 2016, 146, 14281. [CrossRef] [PubMed]

3. Ramana, K.V.; Kandi, S.P.V.B.; Sharada, C.V.; Rao, R.; Mani, R.; Rao, S.D. Invasive Fungal Infections: A Comprehensive Review. Am. J. Infect. Dis. Microbiol. 2013, 1, 64-69. [CrossRef]

4. Wang, Q.; Zhong, C.; Xiao, H. Genetic Engineering of Filamentous Fungi for Efficient Protein Expression and Secretion. Front. Bioeng. Biotechnol. 2020, 8, 293. [CrossRef] [PubMed]

5. Hittinger, C.T.; Alexander, W.G. Constructs and Methods for Genome Editing and Genetic Engineering of Fungi and Protists. U.S. Patent 9879270, 30 January 2018.

6. Perez-Nadales, E.; Nogueira, M.F.A.; Baldin, C.; Castanheira, S.; El Ghalid, M.; Grund, E.; Lengeler, K.; Marchegiani, E.; Mehrotra, P.V.; Moretti, M.; et al. Fungal model systems and the elucidation of pathogenicity determinants. Fungal Genet. Biol. 2014, 70, 42-67. [CrossRef] [PubMed]

7. Dudakova, A.; Spiess, B.; Tangwattanachuleeporn, M.; Sasse, C.; Buchheidt, D.; Weig, M.; Groß, U.; Bader, O. Molecular Tools for the Detection and Deduction of Azole Antifungal Drug Resistance Phenotypes in Aspergillus Species. Clin. Microbiol. Rev. 2017, 30, 1065-1091. [CrossRef] [PubMed]

8. Gaj, T.; Sirk, S.J.; Shui, S.-L.; Liu, J. Genome-Editing Technologies: Principles and Applications. Cold Spring Harb. Perspect. Biol. 2016, 8, a023754. [CrossRef] [PubMed]

9. Hilton, I.B.; Gersbach, C.A. Enabling functional genomics with genome engineering. Genome Res. 2015, 25, 1442-1455. [CrossRef] [PubMed]

10. Chang, S.-S.; Zhang, Z.; Liu, Y. RNA Interference Pathways in Fungi: Mechanisms and Functions. Annu. Rev. Microbiol. 2012, 66, 305-323. [CrossRef]

11. Lax, C.; Tahiri, G.; Patiño-Medina, J.A.; Cánovas-Márquez, J.T.; Pérez-Ruiz, J.A.; Osorio-Concepción, M.; Navarro, E.; Calo, S. The Evolutionary Significance of RNAi in the Fungal Kingdom. Int. J. Mol. Sci. 2020, 21, 9348. [CrossRef]

12. Mousavi, B.; Hedayati, M.T.; Teimoori-Toolabi, L.; Guillot, J.; Alizadeh, A.; Badali, H. cyp51A gene silencing using RNA interference in azole-resistant Aspergillus fumigatus. Mycoses 2015, 58, 699-706. [CrossRef]

13. Martel, C.M.; Parker, J.E.; Bader, O.; Weig, M.; Gross, U.; Warrilow, A.G.S.; Kelly, D.E.; Kelly, S.L. A Clinical Isolate of Candida albicans with Mutations in ERG11 (Encoding Sterol 14 $\alpha$-Demethylase) and ERG5 (Encoding C22 Desaturase) is Cross Resistant to Azoles and Amphotericin B. Antimicrob. Agents Chemother. 2010, 54, 3578-3583. [CrossRef]

14. Sanglard, D.; Ischer, F.; Parkinson, T.; Falconer, D.; Bille, J. Candida albicans Mutations in the Ergosterol Biosynthetic Pathway and Resistance to Several Antifungal Agents. Antimicrob. Agents Chemother. 2003, 47, 2404-2412. [CrossRef]

15. Zhou, Y.; Liao, M.; Zhu, C.; Hu, Y.; Tong, T.; Peng, X.; Li, M.; Feng, M.; Cheng, L.; Ren, B.; et al. ERG3 and ERG11 genes are critical for the pathogenesis of Candida albicans during the oral mucosal infection. Int. J. Oral Sci. 2018, 10, 1-8. [CrossRef]

16. Chang, Z.; Yadav, V.; Lee, S.C.; Heitman, J. Epigenetic mechanisms of drug resistance in fungi. Fungal Genet. Biol. 2019, 132, 103253. [CrossRef]

17. Poças-Fonseca, M.J.; Cabral, C.G.; Manfrão-Netto, J.H.C. Epigenetic manipulation of filamentous fungi for biotechnological applications: A systematic review. Biotechnol. Lett. 2020, 42, 885-904. [CrossRef]

18. Brandão, F.; Esher, S.K.; Ost, K.S.; Pianalto, K.; Nichols, C.B.; Fernandes, L.; Bocca, A.L.; Poças-Fonseca, M.J.; Alspaugh, J.A. HDAC genes play distinct and redundant roles in Cryptococcus neoformans virulence. Sci. Rep. 2018, 8, 1-17. [CrossRef] [PubMed]

19. Brandão, F.A.; Derengowski, L.S.; Albuquerque, P.; Nicola, A.M.; Silva-Pereira, I.; Poças-Fonseca, M.J. Histone deacetylases inhibitors effects on Cryptococcus neoformans major virulence phenotypes. Virulence 2015, 6, 618-630. [CrossRef]

20. Elbashir, S.M.; Harborth, J.; Weber, K.; Tuschl, T. Analysis of gene function in somatic mammalian cells using small interfering RNAs. Methods 2002, 26, 199-213. [CrossRef]

21. Martinez, J.; Patkaniowska, A.; Elbashir, S.M.; Harborth, J.; Hossbach, M.; Urlaub, H.; Meyer, J.; Weber, K.; VanDenburgh, K.; Manninga, H.; et al. Analysis of mammalian gene function using small interfering RNAs. Nucleic Acids Symp. Ser. 2003, 3, 333. [CrossRef] [PubMed] 
22. Alic, N.; Hoddinott, M.P.; Foley, A.; Slack, C.; Piper, M.D.W.; Partridge, L. Detrimental Effects of RNAi: A Cautionary Note on its use in Drosophila Ageing Studies. PLoS ONE 2012, 7, e45367. [CrossRef]

23. Roberts, R.J.; Murray, K. Restriction Endonuclease. CRC Crit. Rev. Biochem. 1976, 4, 123-164. [CrossRef]

24. Brown, D.H.; Slobodkin, I.V.; Kumamoto, C.A. Stable transformation and regulated expression of an inducible reporter construct in Candida albicans using restriction enzyme-mediated integration. Mol. Genet. Genom. 1996, 251, 75-80. [CrossRef]

25. Brown, J.S.; Aufauvre-Brown, A.; Holden, D.W. Insertional mutagenesis of Aspergillus fumigatus. Mol. Genet. Genom. 1998, 259, 327-335. [CrossRef]

26. Warrilow, A.G.S.; Parker, J.E.; Price, C.L.; Nes, W.D.; Kelly, S.L.; Kelly, D.E. In Vitro Biochemical Study of CYP51-Mediated Azole Resistance in Aspergillus fumigatus. Antimicrob. Agents Chemother. 2015, 59, 7771-7778. [CrossRef] [PubMed]

27. Jiang, C.; Dong, D.; Yu, B.; Cai, G.; Wang, X.; Ji, Y.; Peng, Y. Mechanisms of azole resistance in 52 clinical isolates of Candida tropicalis in China. J. Antimicrob. Chemother. 2012, 68, 778-785. [CrossRef] [PubMed]

28. Lartigue, C.; Vashee, S.; Algire, M.A.; Chuang, R.-Y.; Benders, G.A.; Ma, L.; Noskov, V.N.; Denisova, E.A.; Gibson, D.G.; AssadGarcia, N.; et al. Creating Bacterial Strains from Genomes that Have Been Cloned and Engineered in Yeast. Science 2009, 325, 1693-1696. [CrossRef] [PubMed]

29. Kim, Y.G.; Cha, J.; Chandrasegaran, S. Hybrid restriction enzymes: Zinc finger fusions to Fok I cleavage domain. Proc. Natl. Acad. Sci. USA 1996, 93, 1156. [CrossRef] [PubMed]

30. Urnov, F.D.; Rebar, E.J.; Holmes, M.C.; Zhang, H.S.; Gregory, P.D. Genome editing with engineered zinc finger nucleases. Nat. Rev. Genet. 2010, 11, 636-646. [CrossRef]

31. Carroll, D. Genome engineering with zinc-finger nucleases. Genetics 2011, 188, 773-782. [CrossRef]

32. Joung, J.K.; Sander, J.D. TALENs: A widely applicable technology for targeted genome editing. Nat. Rev. Mol. Cell Biol. 2012, 14, 49-55. [CrossRef] [PubMed]

33. Gaj, T.; Gersbach, C.A.; Barbas, C.F. Zfn, Talen and Crispr/Cas-based methods for genome engineering. Trends Biotechnol. 2013, 31,397-405. [CrossRef] [PubMed]

34. Cong, L.; Ran, F.A.; Cox, D.; Lin, S.; Barretto, R.; Habib, N.; Hsu, P.D.; Wu, X.; Jiang, W.; Marraffini, L.A.; et al. Multiplex Genome Engineering using CRISPR/Cas Systems. Science 2013, 339, 819-823. [CrossRef]

35. Mali, P.; Yang, L.; Esvelt, K.M.; Aach, J.; Guell, M.; DiCarlo, J.E.; Norville, J.E.; Church, G.M. RNA-Guided Human Genome Engineering via Cas9. Science 2013, 339, 823-826. [CrossRef]

36. Dicarlo, J.E.; Norville, J.E.; Mali, P.; Rios, X.; Aach, J.; Church, G.M. Genome engineering in Saccharomyces cerevisiae using CRISPR-Cas systems. Nucleic Acids Res. 2013, 41, 4336-4343. [CrossRef]

37. Kennedy, E.M.; Bassit, L.C.; Mueller, H.; Kornepati, A.V.; Bogerd, H.P.; Nie, T.; Chatterjee, P.; Javanbakht, H.; Schinazi, R.F.; Cullen, B.R. Suppression of hepatitis B virus DNA accumulation in chronically infected cells using a bacterial CRISPR/Cas RNA-guided DNA endonuclease. Virology 2015, 476, 196-205. [CrossRef]

38. Ran, F.A.; Hsu, P.D.; Wright, J.; Agarwala, V.; Scott, D.A.; Zhang, F. Genome engineering using the CRISPR-Cas9 system. Nat. Protoc. 2013, 8, 2281-2308. [CrossRef]

39. Li, Y.; Li, S.; Wang, J.; Liu, G. CRISPR/Cas Systems towards Next-Generation Biosensing. Trends Biotechnol. 2019, 37, 730-743. [CrossRef]

40. Wang, J.; Lu, A.; Bei, J.; Zhao, G.; Wang, J. CRISPR/ddCas12a-based programmable and accurate gene regulation. Cell Discov. 2019, 5, 15. [CrossRef] [PubMed]

41. Vercoe, R.B.; Chang, J.T.; Dy, R.L.; Taylor, C.; Gristwood, T.; Clulow, J.S.; Richter, C.; Przybilski, R.; Pitman, A.R.; Fineran, P.C. Cytotoxic Chromosomal Targeting by CRISPR/Cas Systems Can Reshape Bacterial Genomes and Expel or Remodel Pathogenicity Islands. PLoS Genet. 2013, 9, e1003454. [CrossRef] [PubMed]

42. Farboud, B.; Jarvis, E.; Roth, T.L.; Shin, J.; Corn, J.E.; Marson, A.; Meyer, B.J.; Patel, N.H.; Hochstrasser, M.L. Enhanced Genome Editing with Cas9 Ribonucleoprotein in Diverse Cells and Organisms. J. Vis. Exp. 2018, 135, e57350. [CrossRef]

43. Rahimi, H.; Salehiabar, M.; Barsbay, M.; Ghaffarlou, M.; Kavetskyy, T.; Sharafi, A.; Davaran, S.; Chauhan, S.C.; Danafar, H.; Kaboli, S.; et al. Crispr Systems for COVID-19 Diagnosis. ACS Sensors 2021. [CrossRef] [PubMed]

44. Sasano, Y.; Nagasawa, K.; Kaboli, S.; Sugiyama, M.; Harashima, S. CRISPR-PCS: A powerful new approach to inducing multiple chromosome splitting in Saccharomyces cerevisiae. Sci. Rep. 2016, 6, 1-11. [CrossRef] [PubMed]

45. Kuivanen, J.; Wang, Y.-M.J.; Richard, P. Engineering Aspergillus niger for galactaric acid production: Elimination of galactaric acid catabolism by using RNA sequencing and CRISPR/Cas9. Microb. Cell Fact. 2016, 15, 1-9. [CrossRef] [PubMed]

46. Umeyama, T.; Hayashi, Y.; Shimosaka, H.; Inukai, T.; Yamagoe, S.; Takatsuka, S.; Hoshino, Y.; Nagi, M.; Nakamura, S.; Kamei, K.; et al. CRISPR/Cas9 Genome Editing to Demonstrate the Contribution of Cyp51A Gly138Ser to Azole Resistance in Aspergillus fumigatus. Antimicrob. Agents Chemother. 2018, 62. [CrossRef]

47. Gu, Y.; Gao, J.; Cao, M.; Dong, C.; Lian, J.; Huang, L.; Cai, J.; Xu, Z. Construction of a series of episomal plasmids and their application in the development of an efficient CRISPR/Cas9 system in Pichia pastoris. World J. Microbiol. Biotechnol. 2019, 35, 79. [CrossRef] [PubMed]

48. Al Abdallah, Q.; Ge, W.; Fortwendel, J.R. A Simple and Universal System for Gene Manipulation in Aspergillus fumigatus: In Vitro-Assembled Cas9-Guide RNA Ribonucleoproteins Coupled with Microhomology Repair Templates. Msphere 2017, 2, e00446. [CrossRef] [PubMed] 
49. Gong, Z.; Karlsson, A.J. Translocation of cell-penetrating peptides into Candida fungal pathogens. Protein Sci. 2017, 26, 1714-1725. [CrossRef]

50. Farkhani, S.M.; Valizadeh, A.; Karami, H.; Mohammadi, S.; Sohrabi, N.; Badrzadeh, F. Cell penetrating peptides: Efficient vectors for delivery of nanoparticles, nanocarriers, therapeutic and diagnostic molecules. Peptides 2014, 57, 78-94. [CrossRef]

51. Idnurm, A.; Meyer, V. The CRISPR revolution in fungal biology and biotechnology, and beyond. Fungal Biol. Biotechnol. 2018, 5 , 19. [CrossRef]

52. Jinek, M.; Chylinski, K.; Fonfara, I.; Hauer, M.; Doudna, J.A.; Charpentier, E. A Programmable Dual-RNA-Guided DNA Endonuclease in Adaptive Bacterial Immunity. Science 2012, 337, 816-821. [CrossRef] [PubMed]

53. Makarova, K.S.; Koonin, E.V. Annotation and Classification of CRISPR-Cas Systems. In Methods in Molecular Biology; Springer Science and Business Media: Berlin/Heidelberg, Germany, 2015; Volume 1311, pp. 47-75.

54. Horvath, P.; Barrangou, R. CRISPR/Cas the Immune System of Bacteria and Archaea. Science 2010, 327, 167-170. [CrossRef] [PubMed]

55. Jiang, F.; Doudna, J.A. CRISPR-Cas9 Structures and Mechanisms. Annu. Rev. Biophys. 2017, 46, 505-529. [CrossRef] [PubMed]

56. Brandsma, I.; Van Gent, D.C. Pathway choice in DNA double strand break repair: Observations of a balancing act. Genome Integr. 2012, 3, 1-10. [CrossRef]

57. Vyas, V.K.; Barrasa, M.I.; Fink, G.R. A Candida albicans CRISPR system permits genetic engineering of essential genes and gene families. Sci. Adv. 2015, 1, e1500248. [CrossRef]

58. Nguyen, N.; Quail, M.M.F.; Hernday, A.D. An Efficient, Rapid and Recyclable System for CRISPR-Mediated Genome Editing in Candida albicans. Msphere 2017, 2, e00149. [CrossRef]

59. Min, K.; Ichikawa, Y.; Woolford, C.A.; Mitchell, A.P. Candida albicans Gene Deletion with a Transient CRISPR-Cas9 System. Msphere 2016, 1, e00130. [CrossRef]

60. Min, K.; Biermann, A.; Hogan, D.A.; Konopka, J.B. Genetic Analysis ofNDT80Family Transcription Factors in Candida albicans using new CRISPR-Cas9 Approaches. Msphere 2018, 3, e00545. [CrossRef]

61. Enkler, L.; Richer, D.; Marchand, A.L.; Ferrandon, D.; Jossinet, F. Genome engineering in the yeast pathogen Candida glabrata using the CRISPR-Cas9 system. Sci. Rep. 2016, 6, 35766. [CrossRef]

62. Cen, Y.; Timmermans, B.; Souffriau, B.; Thevelein, J.M.; Van Dijck, P. Comparison of genome engineering using the CRISPR-Cas9 system in C. glabrata wild-type and lig4 strains. Fungal Genet. Biol. 2017, 107, 44-50. [CrossRef]

63. Shapiro, R.S.; Chavez, A.; Porter, C.B.M.; Hamblin, M.; Kaas, C.S.; Dicarlo, J.E.; Zeng, G.; Xu, X.; Revtovich, A.V.; Kirienko, N.V.; et al. A CRISPR-Cas9-based gene drive platform for genetic interaction analysis in Candida albicans. Nat. Microbiol. 2018, 3, 73-82 [CrossRef] [PubMed]

64. Ng, H.; Dean, N. Dramatic Improvement of CRISPR/Cas9 Editing in Candida albicans by Increased Single Guide RNA Expression. Msphere 2017, 2. [CrossRef] [PubMed]

65. Halder, V.; Porter, C.B.M.; Chavez, A.; Shapiro, R.S. Design, execution and analysis of CRISPR-Cas9-based deletions and genetic interaction networks in the fungal pathogen Candida albicans. Nat. Protoc. 2019, 14, 955-975. [CrossRef] [PubMed]

66. Lombardi, L.; Turner, S.A.; Zhao, F.; Butler, G. Gene editing in clinical isolates of Candida parapsilosis using CRISPR/Cas9. Sci. Rep. 2017, 7, 1-11. [CrossRef] [PubMed]

67. Lombardi, L.; Oliveira-Pacheco, J.; Butler, G. Plasmid-Based CRISPR-Cas9 Gene Editing in Multiple Candida Species. Msphere 2019, 4, e00125. [CrossRef] [PubMed]

68. Wensing, L.; Sharma, J.; Uthayakumar, D.; Proteau, Y.; Chavez, A.; Shapiro, R.S. A CRISPR Interference Platform for Efficient Genetic Repression in Candida albicans. Msphere 2019, 4, e00002. [CrossRef]

69. Elhariri, M.; Hamza, D.; Elhelw, R.; Refai, M. Eucalyptus Tree: A Potential Source of Cryptococcus neoformansin Egyptian Environment. Int. J. Microbiol. 2016, 2016, 1-5. [CrossRef]

70. Andreou, M.; Cogliati, M.; Kolonitsiou, F.; Stroumpos, C.; Stamouli, V.; Ravazoula, P.; Siagris, D.; Papadogeorgaki, H.; Christofidou, M.; Lekkou, A. Cryptococcus gattii infection in an immunocompetent host in Greece. Med Mycol. Case Rep. 2020, 27, 1-3. [CrossRef]

71. Arras, S.D.M.; Chua, S.M.H.; Wizrah, M.S.I.; Faint, J.A.; Yap, A.S.; Fraser, J.A. Targeted Genome Editing via CRISPR in the Pathogen Cryptococcus neoformans. PLoS ONE 2016, 11, e0164322. [CrossRef]

72. Wang, Y.; Wei, D.; Zhu, X.; Pan, J.; Zhang, P.; Huo, L.; Zhu, X. A 'suicide' CRISPR-Cas9 system to promote gene deletion and restoration by electroporation in Cryptococcus neoformans. Sci. Rep. 2016, 6, 31145. [CrossRef]

73. Fan, Y.; Lin, X. Multiple Applications of a Transient CRISPR-Cas9 Coupled with Electroporation (TRACE) System in the Cryptococcus neoformans Species Complex. Genetics 2018, 208, 1357-1372. [CrossRef] [PubMed]

74. Wang, P. Two Distinct Approaches for CRISPR-Cas9-Mediated Gene Editing in Cryptococcus neoformans and Related Species. Msphere 2018, 3, e00208. [CrossRef]

75. Pagano, L.; Girmenia, C.; Mele, L.; Ricci, P.E.; Tosti, M.; Nosari, A.; Buelli, M.; Picardi, M.; Allione, B.; Corvatta, L.; et al. Infections caused by filamentous fungi in patients with hematologic malignancies. A report of 391 cases by GIMEMA Infection Program. Haematology 2001, 86, 862-870.

76. Pihet, M.; Carrere, J.; Cimon, B.; Chabasse, D.; Delhaes, L.; Symoens, F.; Bouchara, J.-P. Occurrence and relevance of filamentous fungi in respiratory secretions of patients with cystic fibrosis-A review. Med. Mycol. 2009, 47, 387-397. [CrossRef] 
77. Slavin, M.; Van Hal, S.; Sorrell, T.; Lee, A.; Marriott, D.; Daveson, K.; Kennedy, K.; Hajkowicz, K.; Halliday, C.; Athan, E.; et al. Invasive infections due to filamentous fungi other than Aspergillus: Epidemiology and determinants of mortality. Clin. Microbiol. Infect. 2015, 21. [CrossRef] [PubMed]

78. Egbuta, M.A.; Mwanza, M.; Babalola, O.O. Health Risks Associated with Exposure to Filamentous Fungi. Int. J. Environ. Res. Public Health 2017, 14, 719. [CrossRef] [PubMed]

79. Lamoth, F.; Calandra, T. Let's add invasive aspergillosis to the list of influenza complications. Lancet Respir. Med. 2018, 6, 733-735. [CrossRef]

80. Lim, S.-Y.; Son, Y.-E.; Lee, D.-H.; Eom, T.-J.; Kim, M.-J.; Park, H.-S. Function of crzA in Fungal Development and Aflatoxin Production in Aspergillus flavus. Toxins 2019, 11, 567. [CrossRef]

81. Langfelder, K.; Jahn, B.; Gehringer, H.; Schmidt, A.; Wanner, G.; Brakhage, A.A. Identification of a polyketide synthase gene (pksP) of Aspergillus fumigatus involved in conidial pigment biosynthesis and virulence. Med. Microbiol. Immunol. 1998, 187, 79-89. [CrossRef]

82. Yang, G.; Rose, M.S.; Turgeon, B.G.; Yoder, O.C. A polyketide synthase is required for fungal virulence and production of the polyketide T-toxin. Plant Cell 1996, 8, 2139-2150. [CrossRef]

83. Fuller, K.K.; Chen, S.; Loros, J.J.; Dunlap, J.C. Development of the CRISPR/Cas9 System for Targeted Gene Disruption in Aspergillus fumigatus. Eukaryot. Cell 2015, 14, 1073-1080. [CrossRef] [PubMed]

84. Zhang, C.; Meng, X.; Wei, X.; Lu, L. Highly efficient CRISPR mutagenesis by microhomology-mediated end joining in Aspergillus fumigatus. Fungal Genet. Biol. 2016, 86, 47-57. [CrossRef] [PubMed]

85. Nagy, G.; Szebenyi, C.; Csernetics, A.; Vaz, A.G.; Toth, E.J.; Vagvolgyi, C.; Papp, T. Development of a plasmid free CRISPR-Cas9 system for the genetic modification of Mucor circinelloides. Sci. Rep. 2017, 7, 1-10. [CrossRef] [PubMed]

86. Bruni, G.O.; Zhong, K.; Lee, S.C.; Wang, P. Crispr-Cas9 induces point mutation in the mucormycosis fungus Rhizopus delemar. Fungal Genet. Biol. 2019, 124, 1-7. [CrossRef] [PubMed]

87. Agrawal, N.; Dasaradhi, P.V.; Mohmmed, A.; Malhotra, P.; Bhatnagar, R.K.; Mukherjee, S.K. RNA interference: Biology, mechanism, and applications. Microbiol. Mol. Biol. Rev. 2003, 67, 657-685. [CrossRef]

88. Boettcher, M.; McManus, M.T. Choosing the Right Tool for the Job: RNAi, TALEN or CRISPR. Mol. Cell 2015, 58, 575-585. [CrossRef]

89. Zheng, X.; Zheng, P.; Zhang, K.; Cairns, T.C.; Meyer, V.; Sun, J.; Ma, Y. 5 S rRNA Promoter for Guide RNA Expression Enabled Highly Efficient CRISPR/Cas9 Genome Editing in Aspergillus niger. ACS Synth. Biol. 2019, 8, 1568-1574. [CrossRef]

90. Weninger, A.; Fischer, J.E.; Raschmanová, H.; Kniely, C.; Vogl, T.; Glieder, A. Expanding the CRISPR/Cas9 toolkit for Pichia pastoris with efficient donor integration and alternative resistance markers. J. Cell. Biochem. 2018, 119, 3183-3198. [CrossRef]

91. Nødvig, C.S.; Nielsen, J.B.; Kogle, M.E.; Mortensen, U.H. A CRISPR-Cas9 System for Genetic Engineering of Filamentous Fungi. PLoS ONE 2015, 10, e0133085. [CrossRef] [PubMed]

92. Katayama, T.; Tanaka, Y.; Okabe, T.; Nakamura, H.; Fujii, W.; Kitamoto, K.; Maruyama, J.-I. Development of a genome editing technique using the CRISPR/Cas9 system in the industrial filamentous fungus Aspergillus oryzae. Biotechnol. Lett. 2016, 38, 637-642. [CrossRef]

93. Weyda, I.; Yang, L.; Vang, J.; Ahring, B.K.; Lübeck, M.; Lübeck, P.S. A comparison of Agrobacterium-mediated transformation and protoplast-mediated transformation with CRISPR-Cas9 and bipartite gene targeting substrates, as effective gene targeting tools for Aspergillus carbonarius. J. Microbiol. Methods 2017, 135, 26-34. [CrossRef] [PubMed]

94. Wang, Q.; Cobine, P.A.; Coleman, J.J. Efficient genome editing in Fusarium oxysporum based on CRISPR/Cas9 ribonucleoprotein complexes. Fungal Genet. Biol. 2018, 117, 21-29. [CrossRef]

95. Wenderoth, M.; Pinecker, C.; Voß, B.; Fischer, R. Establishment of CRISPR/Cas9 in Alternaria alternata. Fungal Genet. Biol. 2017, 101, 55-60. [CrossRef] [PubMed]

96. Schuster, M.; Schweizer, G.; Reissmann, S.; Kahmann, R. Genome editing in Ustilago maydis using the CRISPR-Cas system. Fungal Genet. Biol. 2016, 89, 3-9. [CrossRef] [PubMed]

97. Zalatan, J.G.; Lee, M.E.; Almeida, R.; Gilbert, L.A.; Whitehead, E.H.; La Russa, M.; Tsai, J.C.; Weissman, J.S.; Dueber, J.E.; Qi, L.S.; et al. Engineering Complex Synthetic Transcriptional Programs with CRISPR RNA Scaffolds. Cell 2015, 160, 339-350. [CrossRef] [PubMed]

98. Shi, S.; Liang, Y.; Zhang, M.M.; Ang, E.L.; Zhao, H. A highly efficient single-step, markerless strategy for multi-copy chromosomal integration of large biochemical pathways in Saccharomyces cerevisiae. Metab. Eng. 2016, 33, 19-27. [CrossRef] [PubMed]

99. Zhang, J.-L.; Peng, Y.-Z.; Liu, D.; Liu, H.; Cao, Y.-X.; Li, B.-Z.; Li, C.; Yuan, Y.-J. Gene repression via multiplex gRNA strategy in Y. lipolytica. Microb. Cell Fact. 2018, 17, 1-13. [CrossRef] [PubMed]

100. Liu, R.; Chen, L.; Jiang, Y.; Zhou, Z.; Zou, G. Efficient genome editing in filamentous fungus Trichoderma reesei using the CRISPR/Cas9 system. Cell Discov. 2015, 1, 15007. [CrossRef] [PubMed]

101. Katayama, T.; Nakamura, H.; Zhang, Y.; Pascal, A.; Fujii, W.; Maruyama, J.-I. Forced Recycling of an AMA1-Based GenomeEditing Plasmid Allows for Efficient Multiple Gene Deletion/Integration in the Industrial Filamentous Fungus Aspergillus oryzae. Appl. Environ. Microbiol. 2018, 85, e01896. [CrossRef]

102. Ronda, C.; Maury, J.; Jakočiunas, T.; Jacobsen, S.A.B.; Germann, S.M.; Harrison, S.J.A.; Borodina, I.; Keasling, J.D.; Jensen, M.K.; Nielsen, A.T. CrEdit: CRISPR mediated multi-loci gene integration in Saccharomyces cerevisiae. Microb. Cell Fact. 2015, $14,1-11$. [CrossRef] 
103. Jakočiūnas, T.; Jensen, M.K.; Keasling, J.D. CRISPR/Cas9 advances engineering of microbial cell factories. Metab. Eng. 2016, 34, 44-59. [CrossRef]

104. Adiego-Pérez, B.; Randazzo, P.; Daran, J.M.; Verwaal, R.A.; Roubos, J.; Daran-Lapujade, P.; Van Der Oost, J. Multiplex genome editing of microorganisms using CRISPR-Cas. FEMS Microbiol. Lett. 2019, 366, 86. [CrossRef] [PubMed]

105. Ozaki, A.; Konishi, R.; Otomo, C.; Kishida, M.; Takayama, S.; Matsumoto, T.; Tanaka, T.; Kondo, A. Metabolic engineering of Schizosaccharomyces pombe via CRISPR-Cas9 genome editing for lactic acid production from glucose and cellobiose. Metab. Eng. Commun. 2017, 5, 60-67. [CrossRef]

106. Lian, J.; Bao, Z.; Hu, S.; Zhao, H. Engineered CRISPR/Cas9 system for multiplex genome engineering of polyploid industrial yeast strains. Biotechnol. Bioeng. 2018, 115, 1630-1635. [CrossRef] [PubMed]

107. Nielsen, J.C. Development of fungal cell factories for the production of secondary metabolites: Linking genomics and metabolism. Synth. Syst. Biotechnol. 2017, 2, 5-12. [CrossRef]

108. Calderone, R.; Sun, N.; Gay-Andrieu, F.; Groutas, W.C.; Weerawarna, P.M.; Prasad, S.; Alex, D.; Li, D. Antifungal drug discovery: The process and outcomes. Futur. Microbiol. 2014, 9, 791-805. [CrossRef]

109. Hara, S.; Jin, F.J.; Takahashi, T.; Koyama, Y. A further study on chromosome minimization by protoplast fusion in Aspergillus oryzae. Mol. Genet. Genom. 2011, 287, 177-187. [CrossRef]

110. Roemer, T.; Boone, C.W. Systems-level antimicrobial drug and drug synergy discovery. Nat. Chem. Biol. 2013, 9, $222-231$. [CrossRef] [PubMed]

111. Qi, L.S.; Larson, M.H.; Gilbert, L.A.; Doudna, J.A.; Weissman, J.S.; Arkin, A.P.; Lim, W.A. Repurposing CRISPR as an RNA-Guided Platform for Sequence-Specific Control of Gene Expression. Cell 2013, 152, 1173-1183. [CrossRef]

112. Kang, J.G.; Park, J.S.; Ko, J.-H.; Kim, Y.-S. Regulation of gene expression by altered promoter methylation using a CRISPR/Cas9mediated epigenetic editing system. Sci. Rep. 2019, 9, 1-12. [CrossRef]

113. Kozel, T.R.; Wickes, B. Fungal Diagnostics. Cold Spring Harb. Perspect. Med. 2014, 4, a019299. [CrossRef] [PubMed]

114. Wickes, B.L.; Wiederhold, N.P. Molecular diagnostics in medical mycology. Nat. Commun. 2018, 9, 5135. [CrossRef] [PubMed]

115. Matsoukas, I.G. Prime Editing: Genome Editing for Rare Genetic Diseases without Double-Strand Breaks or Donor DNA. Front. Genet. 2020, 11, 528. [CrossRef] [PubMed]

116. Anzalone, A.V.; Randolph, P.B.; Davis, J.R.; Sousa, A.A.; Koblan, L.W.; Levy, J.M.; Chen, P.J.; Wilson, C.; Newby, G.A.; Raguram, A.; et al. Search-and-replace genome editing without double-strand breaks or donor DNA. Nat. Cell Biol. 2019, 576, $149-157$. [CrossRef] [PubMed]

117. Abdullah; Jiang, Z.; Hong, X.; Zhang, S.; Yao, R.; Xiao, Y. CRISPR base editing and prime editing: DSB and template-free editing systems for bacteria and plants. Synth. Syst. Biotechnol. 2020, 5, 277-292. [CrossRef] 